\title{
Academic Resilience among Senior Secondary School Students: Influence of Learning Environment
}

\author{
Mihir K. Mallick \& Simranjit kaur \\ Lovely Professional University, Phagwara
}

\begin{abstract}
Learning environment has tremendous effect on the social and emotional development of the student. Learning environment either at school or home has deep impact on students. Academic resilience refers to academic achievement in spite of a challenging or difficult circumstance in the educational process. The study was conducted to explore learning environment and academic resilience of senior secondary school students and to analyze the relationship between learning environment and academic resilience. The nature of the study calls for the descriptive study. 6oo high school students were selected from three regions of Punjab (i.e. Majha, Malwa and Doaba region) through stratified random sampling technique. Self constructed and standardized Learning Environment Scale and Academic Resilience Scale were used for data collection. For analyzing data, parametric statistical techniques were used. Study revealed that boys possessed more scores in academic resilience as compared with girls. Student from urban locality possessed high level of academic resilience. Girl students have high level of learning environment as compared with boys. Locality-wise urban students scored significantly high in learning environment as compared with rural students. Significant positive relation was found between learning environment and academic resilience of senior secondary students.
\end{abstract}

Keywords: Academic Resilience, Learning Environment, Senior Secondary school students

\section{Academic Resilience}

Academic resilience is defined as good academic achievement despite adversity in the educational process. It is the ability to successfully deal with academic drawbacks and challenges that are typical of ordinary academic life (Martin \& Marsh, 2006). In other words, tt is a student's ability to handle the academic pressure, stress and difficulties in the academic or school life e.g. less marks or grades, exam pressure and stress, difficult school work etc. Broadly, academic resilience is a child's ability to maintain academic performance in the face of life.

Academic resilience is a dynamic developmental process that involves many types of protective factors like individual, familial, institutional, or socio-environmental and these factors helps to nurture resilience in the child. Every child has a capacity to be a resilient child but it can only be possible if it is nurtured properly. Home or family is the first institution that encourages developing resilience in the child. After home, child is nurtured at school because they spend large amount of time within the educational system. Academically resilient students are able to transform difficult environments into a source of motivation by maintaining personal high expectations and aspirations, being goal-oriented, having good problem-solving skills, and being socially competent (Wang \& Gordon, 1994). 
In real sense, a child is dependent on the immediate environment i.e. home and the school. Studies revealed that school size, teacher-student ratios, school policies and practices, teaching material, school resources, school facilities, physical conditions, home environment, neighbourhood conditions, parent participation, and number of qualified/experienced teachers all these have an influence on student's educational aspirations, academic achievement, and access to higher education(Halstead, 1974; Rutter, 1979; Walker, et. al, 1995; Higgins, 2004;).

\section{Learning environment}

Environment is a place where a child learns, functions and develops. It may include home, the school, the classroom, friend circle, the overall development of a child including his physical, social, psychological needs (Akem, 2008).

Many scholars have argued that learning environment are variables that can affect students' academic achievement, including performance in examinations (Ajayi, 2010 and Olorundare, 2011). Academic achievement or performance of the student can be improved when healthy and supportive environment prevails at home and school. Some protective factors like parental care and support in home, protective and supportive learning environment at home, a positive relationship between parents and teachers, and good learning environment at school all have positive effect on educational achievement of the children during the schooling (Gutman and Midgley 2000, Henderson and Mapp 2002, Epstein and Sheldon 2006).

The home learning environment is mainly responsible for a child's educational attainment and social development at every stages of the learning process (Bull, Brooking and Campbell 2008; Kendall et al. 2008).

The learning environment in school influence's the learning and achievement goals of a child. It has direct influence on student's learning, their involvement in what is being taught, their motivation level, and their sense of well-being, their belonging, and interaction with teachers. For example, learning environment filled with stimulating educational materials and physical facilities would likely be considered more conducive to learning.

The focus of the present study is to assess learning environment (Parental Control and Encouragement, family support, student teacher relationship, peer influences on learning) of students and how this variable exert influence on the academic resilience of the senior secondary students. There are number of researches on students but little emphasis has been given on studying academic resilience among school students. This is an area that has not been sufficiently explored. Therefore, scope of the study is derived from the limitation of earlier studies which suggests a need for additional research on the study of these variables. The importance of the study is also reflected in the need to understand the relationship of Academic Resilience with Learning Environment.

\section{Objectives of the study:}

1. To explore the level of academic resilience among senior secondary school students.

2. To analyze the perceived learning environment of the senior secondary school students both at home and school.

3. To find out difference among senior secondary school students in their perceived learning environment and academic resilience on the bases of gender and locality. 
4. To analyze the relationship of academic resilience of senior secondary school students with their perceived learning environment.

\section{Hypotheses of the study:}

1. There exists no significant difference between senior secondary school boys and girls in their academic resilience.

2. There exists no significant difference between rural and urban senior secondary school students in their academic resilience.

3. There exists no significant difference between senior secondary school boys and girls in their perceived learning environment.

4. There exists no significant difference between rural and urban senior secondary school students in their perceived learning environment.

5. There exists positive relationship between academic resilience of senior secondary school students with their perceived learning environment.

\section{Method and Procedure:}

Descriptive research method was used for executing the study. For selection of the sample stratified random sampling techniques was used. The sample comprised of 6oo senior secondary school students. Two scales namely Academic Resilience Scale (2015) and Learning Environment Scale (2015) were used for collection of data. Both the scales were developed and standardized by the investigator. The reliability of the Academic Resilience and Learning Environment scale are 0.78 and 0.91 respectively. For analysis of data parametric statistical techniques were used. To explore the trend in terms of academic resilience and learning environment of the senior secondary school students, mean, standard deviation and percentages were calculated. To find out the group difference $t$ test was used. To analyze the relationship co-efficient of correlation was used.

\section{Result and discussion:}

Analyses of data, result and interpretation of findings have been done variable wise keeping in view the objectives of the study. Presentation of analysis follow the below given sequence:

- Result relating to perceived learning environment of the senior secondary school students.

The below given table shows the data relating to perceived learning environment of senior secondary school students at home:

Table No. 1

Learning environment of senior secondary school students at home

\begin{tabular}{|c|c|}
\hline Gender & $\begin{array}{c}\text { Mean Scores in learning environment at } \\
\text { home }\end{array}$ \\
\hline Boys & 89.61 \\
\hline Girls & 92.30 \\
\hline Boys + Girls (Total) & 90.95 \\
\hline
\end{tabular}

(mean score of senior secondary school students in learning environment at home) 
The above table no. 1 shows the mean score of boys and girls in learning environment at home. There is little variation in the mean scores of boys and girls. It can be stated that both boys and girls students possess moderately favourable learning environment at home. Reason may be that irrespective of gender, parents provide facilities to their wards to enhance their learning. It is further elaborated in the below given table:

Table No. 2

\begin{tabular}{|c|c|c|c|c|c|c|c|}
\hline \multirow{2}{*}{ Gender } & \multicolumn{7}{|c|}{ Percentage of levels of learning environment at home } \\
\cline { 2 - 8 } & HF & F & MF & M & MU & U & HU \\
\hline Boys & 10.10 & 2.36 & 42.32 & 29.90 & 5.35 & 9.50 & 0.47 \\
\hline Girls & 11.12 & 7.32 & 56.23 & 14.51 & 5.46 & 3.84 & 1.32 \\
\hline $\begin{array}{c}\text { Boys + Girls } \\
\text { (Total) }\end{array}$ & 10.61 & 4.84 & 49.27 & $\mathbf{2 2 . 2 1}$ & 5.41 & 6.67 & 0.89 \\
\hline
\end{tabular}

(HF=Highly Favourable, F=Favourable, MF=Moderately Favourable, M=Moderate, MU=Moderately Unfavourble, U=Unfavourable, HU= Highly Unfavourable)

The above shows the percentage of senior secondary school students at different levels of learning environment at home. Both boys and girls possess moderately favourable level of learning environment. Girls scored more in learning environment at home than the boys. In total $49.27 \%$ students belong to the moderately favourable level of learning environment at home.

Table No. 3

Learning environment of senior secondary school students at school

\begin{tabular}{|c|c|}
\hline Gender & $\begin{array}{c}\text { Mean Scores in learning environment } \\
\text { at school }\end{array}$ \\
\hline Boys & 110.17 \\
\hline Girls & 104.13 \\
\hline Boys + Girls (Total) & 107.15 \\
\hline
\end{tabular}

(mean score of senior secondary school students in learning environment at school)

A look at the above table shows that boys scored more than girls in learning environment at home. Both (boys and girls) fall under moderate level of learning environment at school. Percentage of the students on different levels of the learning environment at school is further elaborated in the below given table:

Table No. 4

\begin{tabular}{|c|c|c|c|c|c|c|c|}
\hline \multirow{2}{*}{ Gender } & \multicolumn{6}{|c|}{ Percentage of levels of learning environment at school } \\
\cline { 2 - 8 } & HF & F & MF & M & MU & U & HU \\
\hline Boys & 2.32 & 6.53 & 11.79 & 62.32 & 9.80 & 6.72 & 0.52 \\
\hline Girls & 4.51 & 8.56 & 10.83 & 59.63 & 11.70 & 3.42 & 1.35 \\
\hline $\begin{array}{c}\text { Boys + Girls } \\
\text { (Total) }\end{array}$ & 3.42 & 7.54 & 11.31 & 60.97 & 10.75 & 5.07 & 0.93 \\
\hline
\end{tabular}

(HF=Highly Favourable, F=Favourable, MF=Moderately Favourable, M=Moderate, MU=Moderately Unfavourble, U=Unfavourable, HU= Highly Unfavourable)

The above table reflects the percentage of senior secondary school students at different levels of learning environment at school. Both boys and girls possess favourable level of learning environment. In total $60.97 \%$ students possess favourable level of learning environment at school. This may be because of the facilities provided by the school personnel at school. 
- Result relating to level of academic resilience of the senior secondary school students.

The below given table shows the data relating to the levels of academic resilience of senior secondary school students:

Table No. 5

Academic resilience of senior secondary school students

\begin{tabular}{|c|c|}
\hline Gender & Mean Scores in Academic Resilience \\
\hline Boys & $\mathbf{2 0 4 . 1 3}$ \\
\hline Girls & $\mathbf{2 0 0 . 1 2}$ \\
\hline Boys + Girls (Total) & $\mathbf{2 0 2 . 1 2}$ \\
\hline
\end{tabular}

(mean score of senior secondary school students in academic resilience)

It is evident from the above table that boys scored more than girls in academic resilience. Both (boys and girls) fall under average level of academic resilience. Percentage of the students on different levels of the academic resilience is further elaborated in the below given table:

Table No. 6

\begin{tabular}{|c|c|c|c|c|c|c|c|}
\hline \multirow{2}{*}{ Gender } & \multicolumn{7}{|c|}{ Levels of academic resilience } \\
\cline { 2 - 8 } & EH & H & AA & A & BA & L & EL \\
\hline Boys & 2.76 & 77.32 & 1.47 & 12.86 & 1.92 & 2.37 & 1.30 \\
\hline Girls & 5.72 & 49.50 & 18.32 & 16.39 & 3.36 & 4.23 & 2.48 \\
\hline $\begin{array}{c}\text { Boys + Girls } \\
\text { (Total) }\end{array}$ & 4.24 & 63.41 & 9.89 & 14.62 & 2.64 & 3.30 & 1.89 \\
\hline
\end{tabular}

(EH=Extremely High, $\mathrm{H}=$ High, $\mathrm{AA}=$ Above Average, $\mathrm{A}=$ Average $\mathrm{BA}=$ Below Average, $\mathrm{L}=\mathrm{Low}, \mathrm{EL}=$ Extremely Low)

The above table reflects the percentage of senior secondary school students at different levels of academic resilience. Both boys and girls possess high level of academic resilience. In total $63.41 \%$ students are highly academically resilient.

- Result relating to gender and locality wise difference among senior secondary school students in learning environment: The below given table shows the group difference among senior secondary school students in their learning environment on the basis of gender.

Table No. 7

\begin{tabular}{|c|c|c|c|c|c|c|}
\hline \multirow{2}{*}{$\begin{array}{c}\text { Learning } \\
\text { Environment }\end{array}$} & Gender & N & $\begin{array}{c}\text { Mean } \\
\text { Scores }\end{array}$ & SD & t-value & \multicolumn{2}{|c|}{$\begin{array}{c}\text { Levels Of } \\
\text { Significance }\end{array}$} \\
\cline { 2 - 7 } & Boys & 300 & 198.30 & 24.61 & \multirow{2}{*}{0.01} & 0.05 \\
\cline { 2 - 7 } & Girls & 300 & 203.44 & 20.16 & & Significant \\
\hline
\end{tabular}

A look at the table reflects that the mean score of senior secondary school boys and girls are 198.30 and 203.44 respectively. The S.D of boys and girls students are 24.61 and 20.16. The mean difference between the two groups found to be 2.80 which is higher than the tabulated value (2.58 at 0.01 and 1.96 at 0.05 level with $\mathrm{df} 598$ ). This indicates that the t-value is significant both at 0.01 and 0.05 level of significance. Based on the above stated findings, it can be stated that 
the hypothesis no. 1, i.e. "there exists no significant difference between senior secondary school boys and girls in their learning environment" is thus, rejected.

Table No. 8

Group difference among senior secondary school students in their learning environment on the basis of locality.

\begin{tabular}{|c|c|c|c|c|c|c|c|}
\hline \multirow{2}{*}{$\begin{array}{c}\text { Learning } \\
\text { Environment }\end{array}$} & Locality & N & $\begin{array}{c}\text { Mean } \\
\text { Scores }\end{array}$ & SD & t-value & \multicolumn{2}{|c|}{$\begin{array}{c}\text { Levels Of } \\
\text { Significance }\end{array}$} \\
\cline { 2 - 8 } & Rural & 300 & 200.91 & 23.14 & 6.03 & 0.01 & 0.05 \\
\cline { 2 - 5 } & Urban & 300 & 201.96 & 19.30 & & \multicolumn{2}{|c|}{ Significant } \\
\cline { 3 - 8 }
\end{tabular}

The above table reflects the mean score of rural and urban school students are 200.91 and 201.96 respectively. The S.D of students are 23.14 and 19.30. The mean difference between two groups is found to be 6.03 which is higher than the tabled values $(2.58$ at 0.01 and 1.96 at 0.05 level with degree of freedom 598). This indicates that the t-value is significant both at 0.01 and 0.05 level of significance. Thus hypothesis no. 2 "there exists no significant difference between rural and urban senior secondary school students in their learning environment" is rejected.

- Result relating to gender and locality wise difference among senior secondary school students in academic resilience: The below given table shows the group difference among senior secondary school students in their academic resilience on the basis of gender.

Table No. 9

Group difference between senior secondary school boys and girls in their academic resilience

\begin{tabular}{|c|c|c|c|c|c|c|c|}
\hline \multirow{3}{*}{$\begin{array}{l}\text { Academic } \\
\text { Resilience }\end{array}$} & Gender & $\mathbf{N}$ & $\begin{array}{c}\text { Mean } \\
\text { Scores }\end{array}$ & SD & t-value & \multicolumn{2}{|c|}{$\begin{array}{c}\text { Levels Of } \\
\text { Significance }\end{array}$} \\
\hline & Boys & 300 & 204.13 & 19.77 & \multirow[t]{2}{*}{2.67} & 0.01 & 0.05 \\
\hline & Girls & 300 & 200.12 & 16.89 & & \multicolumn{2}{|c|}{ Significant } \\
\hline
\end{tabular}

The above table shows the mean score of senior secondary school boys and girls in their academic resilience are 204.13 and 200.12 respectively. The S.D of boys and girls students are 19.77 and 16.89. The group difference between two groups is found to be 2.67 which is higher than the tabled value (2.58 at 0.01 and 1.96 at 0.05 level with $\mathrm{df} 598$ ). On the basis of the above mentioned finding it can stated that the hypothesis no. 3 i. e. "there exists no significant difference between senior secondary school boys and girls in their academic resilience" is thus, rejected.

Table No. 10

Group difference among senior secondary school students in their academic resilience on the basis of locality

\begin{tabular}{|l|c|c|c|c|c|c|c|}
\hline \multirow{2}{*}{$\begin{array}{l}\text { Academic } \\
\text { Resilience }\end{array}$} & Locality & $\mathbf{N}$ & $\begin{array}{c}\text { Mean } \\
\text { Scores }\end{array}$ & SD & t-value & \multicolumn{2}{|c|}{$\begin{array}{c}\text { Levels Of } \\
\text { Significance }\end{array}$} \\
\cline { 2 - 7 } & Rural & 300 & 200.22 & 18.04 & 1.70 & 0.01 & 0.05 \\
\cline { 2 - 7 } & Urban & 300 & 202.68 & 17.35 & & Not significant \\
\hline
\end{tabular}

The above table shows the mean score of rural and urban high school students are 200.22 and 202.68 respectively. The S.D of students are 18.04 and 17.35. The The group difference between two groups is found to be 1.70 which is lower than the tabled value $(2.58$ at 0.01 and 1.96 
at 0.05 level with $\mathrm{df}$ 598). This indicates that the t-value is nonsignificant both at 0.01 and 0.05 level of significance. On the bases of above finding, we accept the hypothesis no. 4 that is "there exists no significant difference between rural and urban high school students in their academic resilience".

- Result relating to relationship of learning environment with academic resilience of the senior secondary school students.

Table No. 11

\begin{tabular}{|c|c|c|c|}
\hline \multicolumn{4}{|c|}{$\begin{array}{l}\text { Relationship between learning environment of senior secondary students with their } \\
\text { academic resilience. }\end{array}$} \\
\hline & & $\begin{array}{l}\text { Academic } \\
\text { Resilience }\end{array}$ & $\begin{array}{c}\text { Learning } \\
\text { Environment }\end{array}$ \\
\hline \multirow{3}{*}{$\begin{array}{l}\text { Academic } \\
\text { Resilience }\end{array}$} & Pearson Correlation & 1 & $.741^{* 1}$ \\
\hline & Sig. (2-tailed) & & .000 \\
\hline & $\mathrm{N}$ & 600 & 600 \\
\hline \multirow{3}{*}{$\begin{array}{c}\text { Learning } \\
\text { Environment }\end{array}$} & Pearson Correlation & $.741^{\prime \prime}$ & 1 \\
\hline & Sig. (2-tailed) & .000 & \\
\hline & $\mathrm{N}$ & 600 & 600 \\
\hline
\end{tabular}

The above table shows the relationship of learning environment with academic resilience of senior secondary school students. It is observed that there exists a positive relationship between learning environment and academic resilience of senior secondary school students. A look at the table reflects that, coefficient of correlation $\left(\boldsymbol{r}_{\mathbf{1 2}}\right)$ between learning environment and academic resilience of senior secondary students is 0.74 , which is significant at both at 0.01 and 0.05 level of significance. This indicates that there exists a positive relationship between learning environment and academic resilience of senior secondary school students. It shows that learning environment has positive influence on academic resilience of senior secondary school students.

\section{Conclusions:}

The study documented the following conclusions:

- Based on the result analysis, it can be concluded that senior secondary boys and girls differ in their learning environment. Boys and girls possess high level of learning environment at home. This may be due to the learning facilities provided by the parents to their children. But both boys and girls possess average level of learning environment at school because of fewer facilities at schools.

- Significant difference is found in the learning environment of senior secondary school students on the basis of locality of school. Urban students possess more scores in learning environment than rural students. This shows that schools of urban locality have better learning environment than the rural students. This is because of the fact that urban students have better facilities in school as well as at homes.

- At the same time, senior secondary boys and girls show high level of academic resilience. In case of locality of the school, urban (both boys and girls) students possess high level of academic resilience than rural senior secondary school students.

- Significant relation was found between learning environment and academic resilience of senior secondary school students. Schools can play eminent role in making students more resilient. Efforts should be made to bring school policies to strength the school as well as 
home learning environment. So that, the students can be developed not only academically but socially and morally also.

\section{References:}

Aggarwal, Y.P. (200o). Statistical Methods. New Delhi: Sterling Publishers Pvt. Ltd.

Aggrawal, Y.P. (1996). Educational Research. New Delhi: Arya Book Depot, New Delhi.

Ajayi, I.A., H.T. Haastrup \& F.M. Osalusi (2010) "Learning Environment and Secondary School Effectiveness in Nigeria”. Stud Home Comm. Science, 4(3) Pp. 137-142.

Akem, J.A. (2008). Continuous assessment: A practical handbook for schools. Makurdi: Selfers academic press limited.

Artiles, A. J., Harry, B., Reschly, D. J., \& Chinn, P. C. (2002). Over-identification of students of color in special education: A Critical overview. Multicultural Perspectives, 4, 3-10.

Barton, P.E., \& Coley, R.J. (2007). The family: America's smallest school. Retrieved from http://www.ets.org/Media/Education_Topics/pdf/5678_PERCReport_School.

Epstein, J. \& Sheldon, S. (2006). Moving forward: Ideas for research on school, family, and community partnerships. In C. Conrad \& R. Serlin (Eds.), Handbook for research in education: Engaging ideas and enriching inquiry.

Evans, G. W. (2004). The environment of childhood poverty. American Psychologist. 59, 77-92.

Fenning, P., \& Rose, J. (2007). Overrepresentation of African American students in exclusionary discipline: The role of school policy. Urban Education, 42, 536-559.

Garrett, E.H. (2008). Statistics in Psychology and Education. 3rd ed. New York: Longman.

Gutman, L., \& Midgley, C. (2000). The role of protective factors in supporting the academic achievement of poor African American students during the middle school transition. Journal of Youth and Adolescence, 20(2), 223-248.

Henderson, A. \& Mapp, K. (2002). A new wave of evidence. The impact of school, family, and community connections on student achievement. Southwest Educational Development Laboratory (SEDL). Available: http://www.sedl.org/connections/resources/evidence.pdf

Hussain, I., Ahmad, M., Ahmad, S., Suleman, Q., Din, M. Q. and Khalid, N. (2012). A Study to Investigate the Availability of Educational Facilities at Secondary School Level in District Karak. Language in India, Strength for Today and Bright Hope for Tomorrow, India, 12 (10). pp. 234-250

Martin, A., \& Marsh, H. (2006). Academic resilience and its psychological and educational correlates: A construct validity approach. Psychology in Schools, 43(3), $\quad 267-281$.

Masten, A.S. (2001). Ordinary magic: Resilience processes in development. American Psychologist, 56, 227238.

Noam, G. G., \& Hermann, C. A. (2002). Where education and mental health meet: Developmental prevention and early intervention in schools. Development and Psychopathology, 14, 861-875.

Olorundare, A.S. (2011) "Correlates of Poor Academic Performance Of Secondary School Students In The Sciences In Nigeria”. Paper Presented at The Virgina State University, USA, June, 2011.

Reis, S. M., \& McCoach, D. B. (200o).Gifted under achievers: What do we know and where do we go? Gifted Child Quarterly, 44, 152-170.

Wang, M. C., \& Gordon, E. W. (1994). Educational resilience in inner city America. Hillsdale, NJ, Erlbaum.

Dr. Mihir K. Mallick is Professor and Head, School of Education, Lovely Professional University. Simranjit kaur is Ph.D Research Scholar, School of Education, Lovely Professional University. 